\title{
Several Thoughts about Intensive Development to Realizing Win-Win for School-Enterprise Relying on Vocational Education Group
}

\author{
Wang Juan \\ Dept. Name of Organization: Hunan Railway Professional Technology College \\ Zhuzhou, Hunan, China, 412001 \\ emaill:sunwangjuan@126.com
}

Keywords: Vocational education group. Intensive. Win-win

\begin{abstract}
The main goal of vocational education group is to realize vocational education resources optimal allocation, to maximize running quality and efficiency of vocational education, to achieve the vocational education's leapfrog development. It is worth exploring to us how to realize win-win for individual members of the Group.
\end{abstract}

With the change of industrial structure, competition among enterprises has entered the new stage of "human resource competition". On the one hand the phenomenon of "recruitment difficult" in enterprises is becoming increasingly serious, on the other hand the adjustment about employment structure, vocational school students' descending, contradiction about employment difficulty and talent shortage are outstanding. How to combine, how to symbiotic win-win, and how to cultivate talents of high quality for vocational colleges and enterprises, the effective way is running schools in groups.

\section{The Connotation of Vocational Education Group}

"Vocational education group" is one vocational education organization with the leading of famous schools, Colleges and enterprises joint in the same area and industry to realize resource-sharing, complementary advantages, common development. The vocational education group rely on competitive industries, with enhance the core competitiveness of industries as the goal, and concentrate on the conditional higher vocational college, with the industrial scale enterprises, vocational colleges and scientific research, and industry association as the main body, with project cooperation and professional construction as bond, with voluntary and mutually beneficial as principle, these are to meet the needs of our market economic system and economic development, and the only road of taking the group, large-scale, intensive, linkage development.

The Situation Analysis about China's Current Occupation Education Group

(1) The types of vocational education group at present

According to the main body of vocational education run in groups, our country vocational education group can be divided into three types: industry vocational education group, regional vocational education group and composite vocational education group at present.

a) The industry vocational education group. It's one vocational education group that industry lead, industry characteristics school take the lead, take professional as the link, establish close relationship with a number of enterprises, and establish it combined with the same industry, enterprises and scientific research units.special majospecial major

b) The regional vocational education group. It's one vocational education commonwealth led by local government mainly, integrate vocational education resources within the administrative area, dock industry development.

c) The composite vocational education group. It's one vocational education group that the famous schools, industry and government dominate, take professional characteristics as the link , multi subjects of region, industry, enterprise, higher vocational schools establish.

(2) The problems of vocational education group's development at present

a) Lack of policy and financial support from government 
The vocational education group is lack of policy and financial support from government in the development process, and the relevant local government failed to implement effective intervention to vocational education, failed to create external environment that promote vocational education development.

b) Lack of enthusiasm and initiative of enterprises

The goal of government, schools, enterprises win-win far from the ideal because of part of the local government investment is not enough, cooperation effect is not obvious with vocational colleges, part of enterprises' participation is not deep. In practical operation, there are just the vocational colleges dominated, the enthusiasm of enterprises is not high.

c) Not form effective cooperation mechanism, the management is loose, and mere formality

From the actual operation situation, the management of vocational education group is loose, members are independent, don't form an effective cooperation mechanism within the group, and the cooperative's enthusiasm, initiative is not enough in industry enterprises, and diversified cooperation has not yet reached the ideal state between the industry, enterprises, schools and scientific research institutions, the vocational education groups exist, but become formalistic.

Reflections about Vocational Schools and Vocational Education Group Achieving Win-Win

(1) To form the system mechanism of school- enterprise symbiotic development

a) Establishment of group operating mechanism effectively and orderly. The lead school by absorbing the well-known enterprises, industry associations, vocational schools, research institutes within the industry set up organizations of the group and professional construction committee, formulate a series of rules and regulations of vocational education group, establish dynamic mechanism, policy mechanism, safeguard mechanism and exit mechanism in line with the market economic system, and ensure operation of the group effectively and orderly; the vocational education group set up daily offices equipped with full-time staff and special funds to deal with the daily affairs; The vocational education group host a group conference every year and discuss major development problem of group; and organize regular activities of teaching, scientific research and project cooperation that member enterprises and vocational schools of the group participate in together.

b) Establishment of multiparty participation dialogue mechanism. The vocational education group publish requirement reporting about skilled talents regularly, follow and watch closely changes about the occupation post and technical in industry (area), adjust professional structure of vocational colleges and talent training plan timely; the vocational education group hold activities about talent supply and demand meeting, group forum irregularly to realize multi equal consultation and dialogue among government, industry, enterprises, institutions, promote effectively demand docking and exchange information between colleges and universities.

c) Establishment of production-teaching-research cooperative mechanism of "shared responsibility, achievement sharing”. The vocational education group establish production-teaching-research base of technology research and development, extension, service center based on the principles of the mutual benefit and voluntary cooperation; got great achievements in personnel training, application technology research, social services by the way of school-enterprise cooperation, school-school cooperation, multiparty cooperation; product training program for the industry (area), develop training standards and carry out high skills and new technical training actively. The members undertake personnel training of the group together to improve the overall quality of staff, strengthen industrial development in the future.

d) Establishment of daily operation mechanism of group aim at long-term and often. The group set up the secretariat and daily offices equipped with a full-time staff to handle the daily affairs of the group; set up special funds used for daily operation expenditure of the group funded by the government and donated by the members of the unit.

(2) Realization effectively of group resource co-sharing

a) Establishment of information communication platform. The group set up special website and host related publications relying on information exchange platform of the group, and issue timely 
information about industry trends, product market, talent supply and demand status facing the members of the group, and build platform of information co-sharing, technical exchange and business cooperation between the members.

b) Realization of co-sharing of teaching resources and training resources within the group. The group play resource advantage of the lead colleges and backbone enterprises, vocational college, and integrate teaching resources and training resources and co-sharing, schools within the group enjoy free professional personnel training program, curriculum standard ,teaching cases and other teaching resources; set up credit recognition system and enterprise training linking system between the vocational colleges of the group; select and construct a number of practice and training base outside school in the group to meet students' production practice or post practice needs; the member enterprises provide internship positions for the member schools annually.

c) Realization of crossing culture to hire teachers of the group. The group draw up training plan of teachers and establish long-term mechanism of school-enterprise cooperation cultivating and training teachers jointly; form system of professional teacher post practice in the enterprise line and enterprise's technical expert undertake teaching task in the vocational colleges regularly; establish dynamic part-time faculty library, train part-time teachers' teaching ability and improve their teaching level; The main professional of the lead school built the provincial teaching team with enterprise experts participating.

(3) Formation of talent training mode of school-enterprise common culture

a) Formation of dynamic adjustment mechanism of professional settings consistent with industry development needs. The group organize the enterprises and vocational colleges to adjust the professional layout, construct the main professional groups to adapt to the development needs of the region or industry and dock pillar industries, competitive industries and strategic emerging industry effectively, form rational layout, dislocation development pattern between professional of vocational colleges. The size enterprises of group deep participate in formulation of professional planning and talent training program of the lead school, the main professional talent training scheme of other school be formulated by school-enterprise jointly and revise timely.

b) Formation of curriculum construction mechanism of school-enterprise cooperation. The group establish long-term mechanism that enterprise site experts and professional teachers of vocational colleges develop curriculum. School and enterprise complete cooperation construction of the professional curriculum system, the development of main specialized curriculum standard and professional ability test standards.

c) Formation of school-enterprise cooperation teaching mode. The enterprises and vocational colleges of group implement teaching in-depth cooperation following the "teaching, learning, doing" principle, deep teaching reform, carry out teaching mode of task driven and project oriented actively, the enterprise's technical expert take specialized courses teaching, carry out the "order training" among the group members actively.

d) Construction of multi-subject quality evaluation mechanism with school-enterprise participating. School-enterprise cooperation draft personnel training quality evaluation standard, establish quality evaluation system with the students occupation ability as the core, enterprises participate in the quality evaluation of vocational colleges; establish occupation skill appraisal center or occupation qualification examination center relying on the lead colleges and other backbone colleges; promote the "double certificate" system actively, formulate long-term mechanism of school-enterprise cooperation promoting employment for graduates, establish graduates quality investigation mechanism.

(4) The Formation of Sustainable Development Policy Environment

a) The local government or industries pay great attention. The local government and Industry take the vocational education group as an important support for industry development, take construction of group and the lead colleges into the overall development planning of regional or industry; positive guide, actively participate in formulating development planning of group 
construction, and formulate preferential policies, support the group development by means of entrusted project development, help to solve all kinds of problems in the development of the group.

b) The establishment of school-enterprise cooperation funds security mechanism. The local government and industry administrative departments tilt to the group in the funds, set up special funds and project construction funds, provide financial support for the construction of group's training base, promoting the integration process, building information platform, and actively assist the group to open or expand capital channels; The special funds of vocational education group used overall planning by the lead colleges, ensure "earmarks".

c) The establishment of school-enterprise cooperation project support mechanism. The local government and industry administrative departments encourage and support the group to undertake technology research and development project of industry optimization and upgrading, set up the project priority for school-enterprise cooperation projects declared by the group; under the organization of the lead colleges, formulate school-enterprise cooperation projects' management measures and detailed rules, establish evaluation and monitoring system, process monitoring and effective performance evaluation for the school-enterprise cooperation projects.

\section{References}

[1] Kuang Ying. The government how to promote the sustainable development of occupation education group [J]. Journal of Jiangsu Institute of Technology, 2008(23).

[2] Huang Xi. Practice and exploration of training mode of school enterprise cooperation in Vocational Education [J]. school party construction and Ideological education, 2011(5). [3] Xu Jianping. Establishment of a long-term cooperation mechanism based on the principle of mutual benefit and win-win[J]. Chinese higher education, 2010(11). 